\section{REFERENCES}

Baddiley, J. \& Thain, E. M. (1951 a). J. chem. Soc. p. 246. Baddiley, J. \& Thain, E. M. (1951b). J. chem. Soc. p. 2253. Baddiley, J. \& Thain, E. M. (1951c). J. chem. Soc. p. 3421. Baddiley, J. \& Mathias, A. P. (1954). J. chem. Soc. p. 2723.

Barton-Wright, E. C. (1952). The Microbiological Assay of the Vitamin $B$ Complex and Amino Acids. London: Pitman and Sons.

Brown, G. M. \& Snell, E. E. (1953). J. Amer. chem. Soc. 75, 2782.

Eggleston, L. V. \& Hems, R. (1952). Biochem. J. 52, 156.

Hanes, C. S. \& Isherwood, F. A. (1949). Nature, Lond., 164, 1107.

Hoagland, M. B. \& Novelli, G. D. (1954). J. biol. Chem. 207, 767.

Hughes, D. E. (1951). Brit. J. exp. Path. 32, 97.
Hughes, D. E. (1953). Proc. Nutr. Soc. $12,83$.

King, T. E. \& Strong, F. M. (1950). Science, 112, 562.

King. T. E. \& Strong, F. M. (1951). J. biol. Chem. 191, 515.

Krebs, H. A. \& Hems, R. (1953). Biochim. biophys. Acta, $12,172$.

LePage, G. A. (1949). In Manometric Techniques and Tissue Metabolism, 2nd ed. Ed. by Umbreit, W. W., Burris, R. H. \& Stauffer, J. F. Minneapolis: Burgess Publ. Co.

Nossal, P. M. (1951). Biochem. J. 49, 407.

Novelli, G. D. (1953). Physiol. Rev. 33, 525.

Pierpoint, W. S. \& Hughes, D. E. (1952). 2nd Int. Congr. Biochem. Abstracts, p. 91.

Pierpoint, W. S. \& Hughes, D. E. (1954). Biochem. J. 56, 130.

Schmidt, G. \& Thannhauser, S. J. (1943). J. biol. Chem. $149,369$.

\title{
Studies on Sulphatase
}

\section{THE PURIFICATION AND PROPERTIES OF THE ARYLSULPHATASE OF ALCALIGENES METALCALIGENES*}

\author{
BY K. S. DODGSON, B. SPENCER AND K. WILLIAMS \\ Departments of Physiology and Botany, University of Wales, Newport Road, Cardiff
}

(Received 12 April 1955)

A strain of Alcaligenes metalcaligenes, which was isolated from an inter-tidal mud, possessed considerable arylsulphatase activity, and a preliminary purification of the enzyme has been made (Dodgson, Melville, Spencer \& Williams, 1954). The present work describes the further purification of the arylsulphatase and, from consideration of its properties, gives some indication of its possible functional groups.

\section{MATERIALS AND METHODS}

Arylsulphatase substrates. The potassium salts of $p$ nitrophenyl (NPS), $p$-acetylphenyl (APS) and nitrocatechol (NCS) sulphates were prepared by the method described previously (Dodgson et al. 1954).

Other substrates. Potassium chondroitin sulphate was prepared from tracheal cartilage by a modification of the method of Einbinder \& Schubert (1950). The potassium salts of $p$-nitrophenyl phosphate and phenyl acetate were commercial samples.

Determination of arylsulphatase activity. Enzyme activity was determined by the method previously described (Dodgson et al. 1954) and was expressed in terms of nitrogen, as determined by the micro-Kjeldahl method of Markham (1942), or protein, as determined by the method of Lowry, Roseborough, Farr \& Randall (1951).

Determination of nucleic acid. Ribonucleic and deoxyribonucleic acids were estimated by the method of Schmidt

* Part 10: Dodgson, Rose \& Spencer (1955).
\& Thannhauser (1945). The ratio of the spectrophoto. metric readings at 280 and $260 \mathrm{~m} \mu$. was used to locate nucleic acid in the electrophoresis experiments (Warburg \& Christian, 1941).

\section{EXPERIMENTAL AND RESULTS}

\section{Preparation of enzyme concentrate}

The enzyme was concentrated to stage $B$ as previously described (Dodgson et al. 1954). Attempts to purify the enzyme further by ammonium sulphate fractionation and adsorption techniques with ion-exchange resins, alumina, calcium carbonate and benzoic acid were of little value since losses in total enzyme activity were not compensated by the degree of purification achieved. However, paper electrophoresis of the stage $B$ enzyme suggested that considerable purification was possible by the use of this technique.

Electrophoresis experiments. The enzyme solution $(0 \cdot 1 \mathrm{ml}$. of a solution of a $0.1 \mathrm{~g}$. stage $B$ in $0.6 \mathrm{ml}$. of $0.1 \mathrm{~m}$ phosphate buffer, $\mathrm{pH} \mathrm{8.0)}$ was run for $18 \mathrm{hr}$. on vertically held Whatman no. 100 filter paper at $110 \mathrm{v}$ in the presence of $0.1 \mathrm{M}$ phosphate, $\mathrm{pH} 8 \cdot 0$. The paper was dried at room temperature and cut into $1 \mathrm{~cm}$. strips. Protein was located by staining with bromophenol blue (see Flynn \& de Mayo 1951) and arylsulphatase activity was located, according to the method described by Dodgson, Spencer \& Thomas (1955), by incubating each strip with $0.5 \mathrm{ml}$. of $0.0015 \mathrm{M}$ NPS in $0.1 \mathrm{M}$ phosphate at $\mathrm{pH} 8 \cdot 75$. 
The enzyme migrated towards the anode and was the fastest-moving protein component. In subsequent experiments the enzyme was eluted from the relevant portion of the paper with water.

Table 1. Stages in the purification of the arylsulphatase of Alcaligenes metalcaligenes

Enzyme activity was measured against 0.0015 M NPS in $0.1 \mathrm{~m}$ phosphate buffer, $\mathrm{pH} 8.75$ at $37.5^{\circ}$ for $1 \mathrm{hr}$. One NPS unit equals $1 \mu \mathrm{g}$. $p$-nitrophenol liberated under these conditions.

\begin{tabular}{|c|c|c|c|}
\hline & \multicolumn{3}{|c|}{ Enzyme activity in NPS units } \\
\hline & per mg. $\mathbf{N}$ & $\begin{array}{c}\text { per mg. } \\
\text { RNA } \\
\text { phosphorus }\end{array}$ & $\begin{array}{c}\text { Enzyme } \\
\text { activity } \\
\text { remaining } \\
(\%)\end{array}$ \\
\hline Whole cells & 53 & - & 100 \\
\hline Stage $A$ & $\mathbf{3 7 0}$ & 26000 & 80 \\
\hline Stage $B$ & 1190 & 25400 & 50 \\
\hline $\begin{array}{l}\text { Electrophoretically } \\
\text { purified enzyme }\end{array}$ & 16500 & $\mathbf{3 4} \mathbf{3 0 0}$ & 35 \\
\hline
\end{tabular}

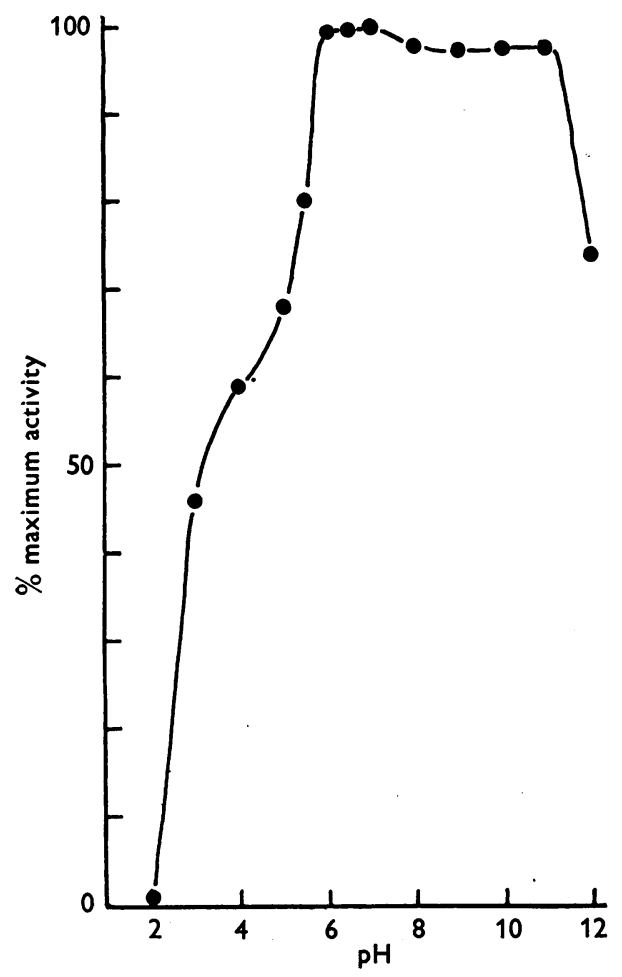

Fig. 1. Inactivation of the arylsulphatase of $A$. metalcaligenes with $\mathrm{pH}$. The enzyme solution was adjusted to the required $\mathrm{pH}$ with $\mathrm{HCl}$ or $\mathrm{NaOH}$ and allowed to stand at $0^{\circ}$ for $45 \mathrm{~min}$. An equal volume of $0.2 \mathrm{M}$ phosphate buffer $\mathrm{pH} 8 \cdot 75$ was then added, the $\mathrm{pH}$ of the mixture checked to $\mathrm{pH} 8 \cdot 75$, and the arylsulphatase activity determined by the use of NPS under the optimum conditions.
Spectrophotometric examination of the eluate revealed a peak of absorption at $260 \mathrm{~m} \mu$., a region where nucleic acid absorbs strongly. Estimation of the organically bound phosphate present in the eluate by the method of Schmidt \& Thannhauser (1945) also indicated the presence of nucleic acid. The results given in Table 1 suggested a correlation between enzyme activity at various stages of purification and the concentration of ribonucleic acid phosphorus. A similar correlation was also noted during the preliminary attempts to purify the enzyme by ammonium sulphate fractionation or by adsorption techniques. It was subsequently noted that the curve showing the enzyme activity remaining after allowing the enzyme to stand at various $\mathrm{pH}$ values for $\mathbf{4 5} \mathrm{min}$. before assay (Fig. 1) was substantially the same as the curve showing the effect on $\mathrm{pH}$ on the degree of polymerization of deoxyribonucleic acid (Gulland, Jordan \& Threlfall, 1947). A particular point of comparison was the sharp drop in viscosity of deoxyribonucleic acid and activity of the enzyme which occurred below pH 6 and above pH 11.

Binkley (1952, 1954) has indicated that the peptidase activities of a cell are a property of the polynucleotides of the cell. In view of the experimental results obtained in the present work the possibility that polynucleotides were also responsible for arylsulphatase activity had to be considered. The fact that incubation with crystalline ribonuclease had no effect on the arylsulphatase activity did not necessarily rule it out, but the rapid inactivation of the arylsulphatase by trypsin showed that the enzyme was essentially protein in nature (see Binkley, 1954). However, the possibility that protein associated with nucleic acid was responsible for arylsulphatase activity could not be excluded at this stage.

Separation of the nucleic acid and the arylsulphatase. When the paper-electrophoresis runs were prolonged beyond $18 \mathrm{hr}$. there was some indication of separation of nucleic acid and enzyme (Fig. 2). Subsequently the portion of the paper containing the bulk of the arylsulphatase activity was cut out, the enzyme eluted with water and the eluate was concentrated by freeze-drying. Paper electrophoresis of the concentrated solution resulted in a still greater degree of separation (Fig. 2), and arylsulphatase, free from nucleic acid, could be eluted from the paper. The apparent association of nucleic acid and arylsulphatase activity observed in the preliminary experiments must therefore be regarded as fortuitous.

Electrophoretic concentration of the enzyme. A $17 \%(\mathrm{w} / \mathrm{v})$ solution of the stage $B$ powder in water was run on Whatman no. 100 paper during $24 \mathrm{hr}$. under the conditions described previously. Several papers, each carrying $0.1 \mathrm{ml}$. of the enzyme 
solution, were run simultaneously and the enzyme and nucleic acid were subsequently located on one of the papers. The other papers were cut so as to retain the bulk of the arylsulphatase activity with a minimum contamination from nucleic acid, suspended in water and dialysed overnight. The
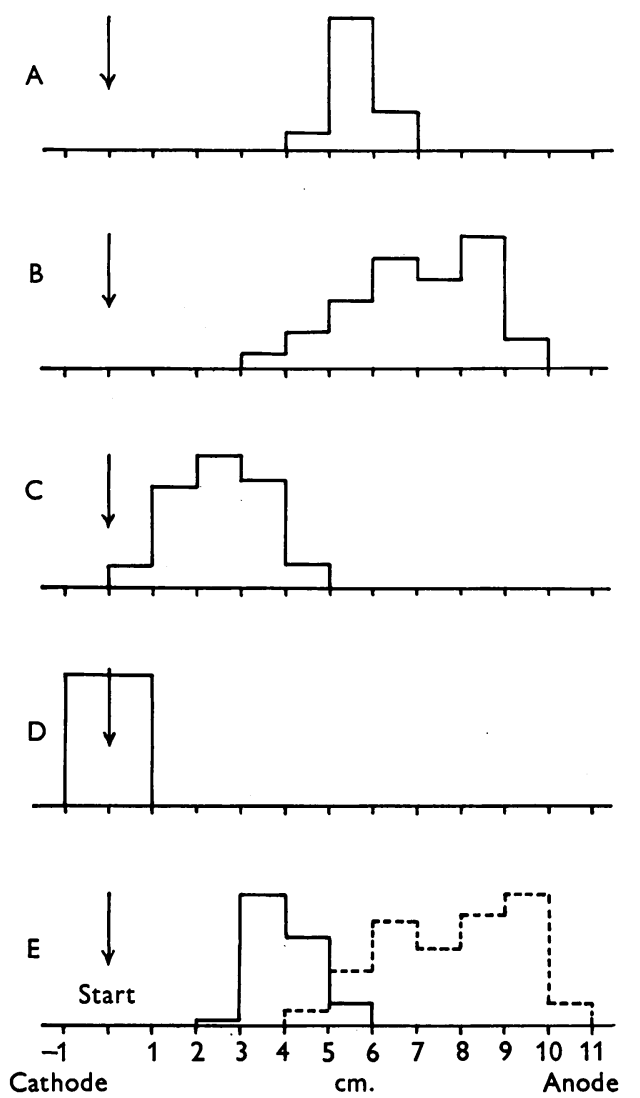

Fig. 2. Paper electrophoresis. Stage $B$ concentrate was run on vertically held Whatman no. 100 paper in $0.1 \mathrm{M}$ phosphate buffer $\mathrm{pH} 8.0$ for $24 \mathrm{hr}$. at $110 \mathrm{v}$ and the positions of the arylsulphatase (A), nucleic acid (B), esterase (C) and phosphatase (D) were determined by the method described in the text. A better separation (E) of nucleic acid (interrupted line) and arylsulphatase (solid line) was achieved by re-running, under the same conditions, a concentrate of the arylsulphatase eluted from the sixth $\mathrm{cm}$. of $\mathrm{A}$ (see text). The distribution patterns shown have been drawn with an arbitary scale.

filtered solution was freeze-dried to give a colourless powder which was stable at $0^{\circ}$. One g. of the powder liberated $1.480 \mathrm{~g}$. $p$-nitrophenol from $0.0015 \mathrm{M}$ NPS in $0.1 \mathrm{M}$ phosphate, $\mathrm{pH} 8.75$ at $37^{\circ}$ over $1 \mathrm{hr}$. On a nitrogen basis this represents a 300 -fold purification of the enzyme with a retention of $35 \%$ of the original activity (Table 1).
Subsequent experiments were performed with enzyme concentrates prepared in this way.

Presence of other enzymes in the concentrate. An esterase, active towards phenyl acetate, and a phosphatase, active towards $p$-nitrophenyl phosphate, were present at stage $B$. The behaviour of the esterase during electrophoresis was followed by incubating $1 \mathrm{~cm}$. strips of the paper with a saturated solution of phenyl acetate in $0.1 \mathrm{~m}$ phosphate, pH 8.75, and subsequently treating according to the directions of Aldridge (1954). Phosphatase was located by incubating the strips with $0.01 \mathrm{~m}$ disodium $p$-nitrophenyl phosphate in $0.1 \mathrm{M}$ phosphate, $\mathrm{pH} 8 \cdot 75$, and subsequent detection of liberated $p$-nitrophenol. The two enzymes migrated towards the anode at much slower rates than the arylsulphatase and were thus eliminated during the purification procedure by cutting the papers as described (Fig. 2).

The electrophoretically purified enzyme was free from chondrosulphatase since it did not liberate inorganic sulphate from a solution $(0 \cdot 75 \%, \mathrm{w} / \mathrm{v})$ of potassium chondroitin sulphate in $0.5 \mathrm{M}$ acetate at pH's 7 and 8. It has been previously reported that the stage $B$ concentrate contains no glycosulphatase or glucuronidase activity (Dodgson et al. 1954).

\section{Properties of the enzyme concentrate}

The enzyme concentrate gave $\mathrm{pH} /$ activity and substrate concentration/activity curves which were very similar to those obtained previously with

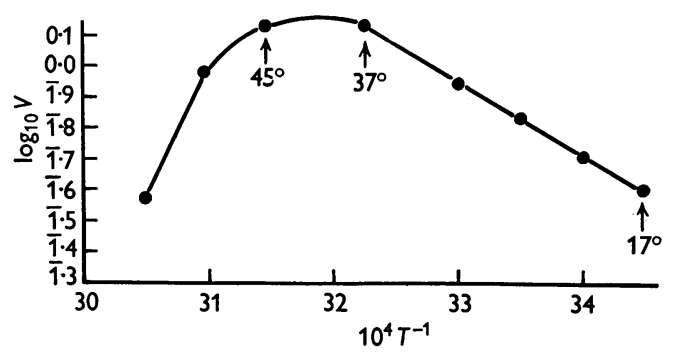

Fig. 3. The effect of temperature on the activity of arylsulphatase against NPS. The results are plotted in the form $1 / T\left({ }^{\circ} \mathrm{K}\right)$ against $\log _{10} V$, for calculation of the activation energy of the enzyme.

the stage $B$ enzyme (see Dodgson et al. 1954). The ratio of the observed activities towards the three substrates under the respective optimum conditions was $5 \cdot 2$ (APS) : $5 \cdot 0$ (NPS) : $1 \cdot 0$ (NCS) calculated on a molar basis; when account was taken of the inhibition by excess of substrate and the true $V_{\max }$. calculated (Lineweaver \& Burk, 1934, case III), the ratio became $15 \cdot 1: 14 \cdot 4: 1 \cdot 0$. The Michaelis constants, $K_{m}$, for the three substrates, calculated 
by the method of Lineweaver \& Burk were $9.0 \times 10^{-4} \mathrm{M}$ (APS), $4.75 \times 10^{-4} \mathrm{M}$ (NPS) and $2.2 \times 10^{-4} \mathrm{M}$ (NCS), showing that the affinity of the enzyme for substrate $\left(1 / K_{m}\right)$ was greatest with NCS.

Table 2. The effect of inhibitors on the arylsulphatase of Alcaligenes metalcaligenes

Inhibitors were allowed to act as described in the text and the residual arylsulphatase activity was measured for $1 \mathrm{hr}$. at $37^{\circ}$ against NPS under the optimum conditions.

\begin{tabular}{|c|c|c|}
\hline Inhibitor & $\begin{array}{c}\text { Concentration } \\
\text { of inhibitor } \\
\text { M }\end{array}$ & $\begin{array}{c}\% \\
\text { inhibition }\end{array}$ \\
\hline $\mathrm{NaCl}$ & 0.025 & 0 \\
\hline $\mathrm{NaF}$ & $0 \cdot 025$ & 0 \\
\hline $\mathrm{Na}_{2} \mathrm{SO}_{4}$ & 0.025 & 0 \\
\hline $\mathrm{NaHSO}_{3}$ & 0.025 & 17 \\
\hline $\mathrm{NaCN}$ & $\begin{array}{l}0.025 \\
0.0125 \\
0.0063\end{array}$ & $\begin{array}{l}82 \\
69 \\
51\end{array}$ \\
\hline $\mathrm{Na}_{2} \mathrm{SO}_{3}$ & $\begin{array}{l}0 \cdot 025 \\
0 \cdot 0125 \\
0 \cdot 0063\end{array}$ & $\begin{array}{l}34 \\
28 \\
19\end{array}$ \\
\hline $\mathrm{BaCl}_{2}$ & $0 \cdot 025$ & 100 \\
\hline Urea & 0.025 & 0 \\
\hline Glucose 6-sulphate & 0.025 . & 17 \\
\hline Potassium ethyl sulphate & $0 \cdot 025$ & 12 \\
\hline Sodium benzenesulphonate & $0 \cdot 025$ & 33 \\
\hline Phenylhydrazine & $\begin{array}{l}0 \cdot 0001 \\
0 \cdot 00005 \\
0 \cdot 000025\end{array}$ & $\begin{array}{l}87 \\
73 \\
52\end{array}$ \\
\hline Hydrazine & 0.025 & 43 \\
\hline Semicarbazide & $0 \cdot 025$ & 21 \\
\hline Thiosemicarbazide & 0.025 & 33 \\
\hline Dimedone & $0.5 \%(w / v)$ & 27 \\
\hline Girards' reagent $\mathbf{P}$ & $2.5 \%(w / v)$ & 25 \\
\hline Hydroxylamine & 0.025 & 97. \\
\hline Phosphate* (pH 6.3 and 8.75) & $0 \cdot 1$ & 0 \\
\hline
\end{tabular}

* The activity in the presence of phosphate was compared against control determinations in which enzyme and substrate, previously adjusted to the appropriate $\mathrm{pH}$ with $\mathrm{NaOH}$ or $\mathrm{HCl}$, were incubated together in the absence of phosphate buffer. The pH of these controls did not vary during the course of the experiment.

The heat of activation was determined by measuring the activity of the enzyme at various temperatures against NPS under the optimum conditions and using a $30 \mathrm{~min}$. incubation period. The plot of $1 / T$ (in ${ }^{\circ} \mathrm{K}$ ) against $\log _{10} V$ (Fig. 3) was a straight line over the range $17-37^{\circ}$ and gave a heat of activation (Arrhenius, 1889) of $11 \mathrm{kcal} . /$ mole. This value should be compared with that for ox-liver sulphatase A, $14 \mathrm{kcal} . / \mathrm{mole}$ at high enzyme concentrations (Roy, 1953), ox-liver sulphatase B, $13 \mathrm{kcal} . / \mathrm{mole}$ (Roy, 1954), and the arylsulphatase of Charonia lampas, $28 \mathrm{kcal} . / \mathrm{mole}$ (Soda \& Yoshida, 1948).

The effect of inhibitors. A number of compounds which were known to inhibit arylsulphatases from other sources were tested against the Alcaligenes enzyme. The inhibitor $(0.3 \mathrm{ml}$.) in $0.1 \mathrm{M}$ phosphate buffer adjusted to $\mathrm{pH} 8.75$ was mixed with $0.3 \mathrm{ml}$. enzyme solution and the mixture kept at $37^{\circ}$ for $15 \mathrm{~min}$. before the addition of $0.6 \mathrm{ml} .0 .0015 \mathrm{M}$ NPS in $0 \cdot 1 \mathrm{M}$ phosphate, $\mathrm{pH} 8 \cdot 75$. After incubation for $1 \mathrm{hr}$. the liberated $p$-nitrophenol was estimated in the usual way. The results are listed in Table 2. The Alcaligenes enzyme was inhibited by aldehyde reagents such as cyanide, phenylhydrazine and hydroxylamine. In this respect it resembles the arylsulphatases of clarase (Dzialoszynski, 1950), Takadiastase (Robinson, Smith, Spencer \& Williams, 1952) and the locust (Robinson, Smith \& Williams, 1953). In contrast, the enzyme of the limpet (Dodgson \& Spencer, unpublished.results) and the soluble enzymes of rabbit (Maengwyn-Davies \& Friedenwald, 1954) and human livers (Dodgson, Spencer \& Wynn, unpublished work) are largely unaffected by the aldehyde reagents but are strongly inhibited by phosphate and fluoride. These points support the suggestions of Dodgson \& Spencer (1953) and Roy (1953) that two distinct types of arylsulphatases occur in nature.

\section{The functional groups of the enzyme}

The arylsulphatase of Alcaligenes showed marked variation in the substrate concentration/activity curves at different $\mathrm{pH}$ values (see Fig. 4) and a

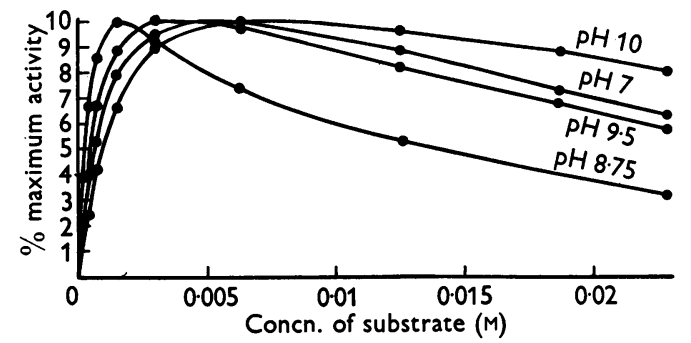

Fig. 4. Effect of $\mathrm{pH}$ on the substrate concentration/ activity curves for NPS.

plot of the $\mathrm{p} K_{m}$ values $\left(-\log _{10} K_{m}\right)$ against $\mathrm{pH}$ gave curves which were very similar for NPS, APS and NCS (Fig. 5). These curves have horizontal portions joined together by positive or negative slopes which are probably 1-unit in character. Dixon (1953) has shown that information about possible functional groups of enzymes can be obtained by consideration of the variation of the dissociation constant $\left(K_{s}\right)$ of the enzyme-substrate 
complex with $\mathrm{pH}$. Direct determination of $K_{s}$ was not possible in the present case, but if it can be shown that the $K_{m}$ values derived for Alcaligenes arylsulphatase are a good approximation to the $K_{s}$ values for this enzyme it is possible to interpret the curves in Fig. 5 according to Dixon's (1953) rules 9 and 10. According to Briggs \& Haldane (1925), for the reaction

$$
\mathrm{E}+\mathrm{S} \underset{k_{2}}{\stackrel{k_{1}}{\rightleftharpoons}} \mathrm{ES} \stackrel{k_{3}}{\rightarrow} \mathrm{E}+\text { products, }
$$

$K_{m}=\left(k_{2}+k_{3}\right) / k_{1}$. When $k_{3}$ is negligible compared with $k_{2}, K_{m}$ is equal to the dissociation constant of the enzyme-substrate complex, $K_{m}=K_{s}=k_{2} / k_{1}$ (Michaelis \& Menten, 1913). For the Alcaligenes enzyme both the $K_{m}$ and the $V_{\max }\left[k_{3}(e)\right]$ values of the enzyme for the three substrates were in the

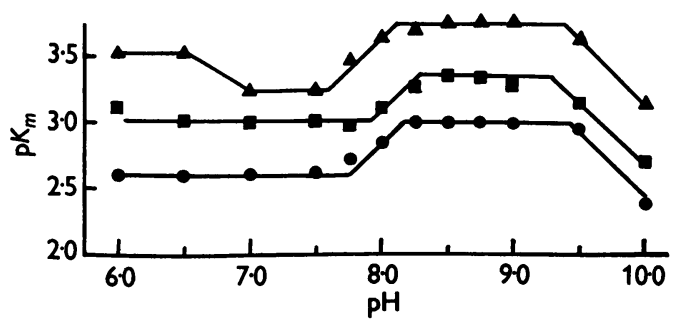

Fig. 5. Variation of $\mathrm{p} K_{m}$ with $\mathrm{pH}$ (cf. Dixon, 1953). NCS, $\triangle$; NPS, ø; APS, $\bullet$

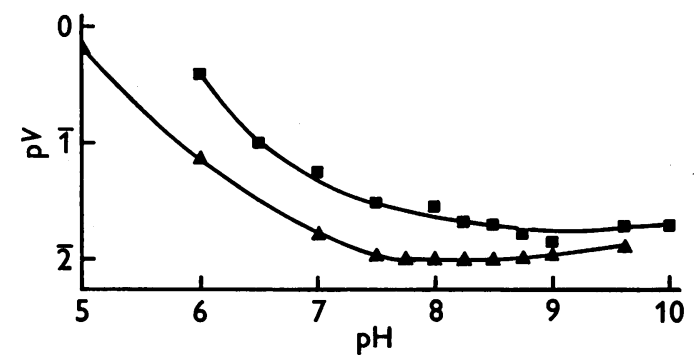

Fig. 6. Variation of $\mathrm{p} V$ with $\mathrm{pH}$. NCS, $\Delta$; NPS, $\square$.

descending order APS, NPS, NCS, and it was thus impossible to assess the magnitude of the contribution of $k_{3}$ to $K_{m}=\left(k_{2}+k_{3}\right) / k_{1}$. However, Dixon (1953) states that in such indeterminate cases rules 9 and 10 can be applied to the $\mathrm{p} K_{m} / \mathrm{pH}$ curve in $\mathrm{pH}$ regions where the $\mathrm{pV} / \mathrm{pH}$ curve (Fig. 6) is either (1) horizontal or (2) has non-whole-number slopes or is curved, provided that, in the second case, the $\mathrm{p} K_{m} / \mathrm{pH}$ graph has whole-number slopes (e.g. 0- or 1-unit slopes) in the same $\mathrm{pH}$ regions.

Fig. 6 shows the plot of $\mathrm{p} V\left(\mathrm{p} V=-\log _{10} V_{\text {max. }}\right)$ against $\mathrm{pH}$ for NPS and NCS, from which, using Fig. 5, it may be deduced that Dixon's rules are applicable in the present case.
According to rule 10 the changes in direction shown in the regions of $\mathrm{pH} 8.2$ and 9.4 in Fig. 5 for all three curves reflect $\mathrm{p} K$ values of ionizing substrate groupings or substrate-binding enzyme groupings. Fig. 7 shows the titration curves obtained by titrating the free arylsulphuric acids with alkali, and it is apparent that none of these compounds possess groupings with $\mathrm{p} K$ values at 8.2 or 9.4 . It may thus be presumed that the changes of direction at these two $\mathrm{pH}$ values indicate ionizing substrate-binding groups in the enzyme.

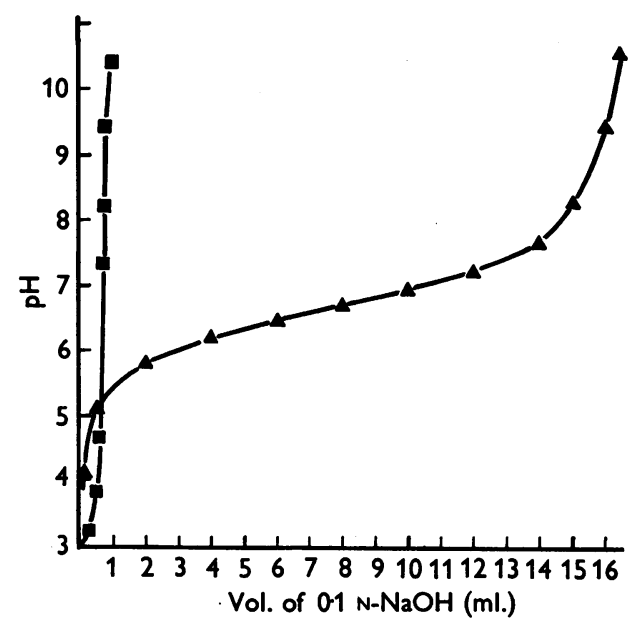

Fig. 7. Titration curves for NCS, $\Delta$; NPS and APS, $\square$.

The change in direction which occurs in each curve between $\mathrm{pH} 7.5$ and 8 reflects a dissociation of enzyme-substrate complex groupings. Further inflexions in the NCS curve are present at $\mathrm{pH}$ values $7 \cdot 0$ and 6.5 , the former again due to dissociation of enzyme-substrate complex. The inflexion at $\mathrm{pH} 6.5$ according to rule 10 could be due to dissociation of either enzyme or substrate, but almost certainly the latter, since it is not present in the other two curves. The titration curve for NCS (Fig. 7) shows the presence of a substrate group (presumably the free phenolic group), with a $\mathrm{pK}$ in the region of this $\mathrm{pH}$.

A search of the literature gave no clue as to the nature of the substrate-binding enzyme group with $\mathrm{p} K \mathbf{8 \cdot 2}$, but the group with $\mathrm{p} K \mathbf{9 \cdot 4}$ could possibly be $\epsilon$ - or $\alpha$-amino, sulphydryl or phenolic, which in proteins dissociate in the region of this $\mathrm{pH}$. Since phosphate did not inhibit enzyme activity (see Table 2) it was assumed that phosphate buffer was not affecting the $\mathrm{p} K_{m} / \mathrm{pH}$ curves (cf. Alberty \& Massey, 1954).

The action of group-specific protein reagents. It was considered that a study of the effects of certain 
group-specific protein reagents might indicate the nature of the ionizing groupings. Equal quantities of the reagent and enzyme were incubated together at $37^{\circ}$ for $1 \mathrm{hr}$., in the presence of $0.1 \mathrm{~m}$ phosphate adjusted to the required $\mathrm{pH}$. The mixture was subsequently dialysed overnight, the $\mathrm{pH}$ adjusted to 8.75 and the residual enzyme activity determined, using NPS as substrate. Suitable control experiments were made. The results (Table 3 ) are in contrast with those of Maengwyn-Davies \& Friedenwald (1954) for the soluble arylsulphatases of rabbit liver. amino groups. It must be borne in mind in the interpretation of these results that the presence of at least two substrate-binding groups in the enzyme molecule provides more than one active centre which might be susceptible to the action of protein-specific reagents. Moreover, Table 2 shows that reagents which are known to react with carbonyl groupings (and particularly aldehydic groups) all partially inhibit the Alcaligenes enzyme. On similar evidence it has been suggested by Rosenfeld \& Ruchelman (1940) that the arylsulphatases of Takadiastase contains an aldehydic

Table 3. The effect of protein group specific reagents on the arylsulphatase activity of Alcaligenes metalcaligenes

Residual enzyme activity was measured against NPS under the optimum conditions.

\begin{tabular}{|c|c|c|c|c|}
\hline Protein reagent & $\begin{array}{c}\mathrm{pH} \text { of } \\
\text { reaction } \\
\text { mixture }\end{array}$ & $\begin{array}{l}\text { Final concn. } \\
\text { of reagent }\end{array}$ & $\begin{array}{c}\text { Enzyme } \\
\text { activity } \\
\text { remaining } \\
(\%)\end{array}$ & $\begin{array}{l}\text { Protein groups known } \\
\text { to be affected }\end{array}$ \\
\hline Glyoxal & $7 \cdot 3$ & $5 \%(w / v)$ & 6 & Guanidyl \\
\hline Iodoacetic acid & $7 \cdot 4$ & $0 \cdot 05 \mathrm{M}$ & 0 & Amino, indole, sulphydryl, phenol \\
\hline 2:4-Dinitrofluorobenzene & $7 \cdot 8$ & $0.0005 \mathrm{M}$ & 100 & $\begin{array}{l}\text { Amino, imidazole, sulphydryl, } \\
\text { phenol }\end{array}$ \\
\hline$p$-Chloromercuribenzoic acid & $8 \cdot 0$ & $0.00025 \mathrm{M}$ & 51 & Sulphydryl \\
\hline $\begin{array}{l}p \text {-Chloromercuribenzoic acid } \\
+0.005 \text { M cysteine }\end{array}$ & $8 \cdot 0$ & $0.0025 \mathrm{M}$ & 55 & - \\
\hline $\begin{array}{l}p \text {-Chloromercuribenzoic acid } \\
+0.005 \mathrm{~m} \text { glutathione }\end{array}$ & $8 \cdot 0$ & $0.0025 \mathrm{M}$ & 51 & - \\
\hline Diazotized sulphanilic acid & $7 \cdot 1$ & $0 \cdot 125 \%(w / v)$ & 0 & $\begin{array}{l}\text { Amino, imidazole, } \mathrm{CH} \text { vicinal to } \\
\mathrm{OH} \text { of tyrosine etc. }\end{array}$ \\
\hline Formaldehyde & $7 \cdot 4$ & $20 \%(w / v)$ & 0 & Amino, guanidyl \\
\hline Formaldehyde $+0 \cdot 1 \mathrm{~g}$. alanine & $11 \cdot 0$ & $20 \%(w / v)$ & 0 & $\begin{array}{l}\text { Amino, guanidyl, indole, amide, } \\
\text { sulphydryl, carboxyl }\end{array}$ \\
\hline Iodine & $8 \cdot 75$ & $0.005 \mathrm{M}$ & 9 & Phenolic \\
\hline Acetic anhydride & $\begin{array}{c}5 \cdot 5 \\
(\text { final } \mathrm{pH})\end{array}$ & $6 \%(w / v)$ & 7 & Amino \\
\hline
\end{tabular}

\section{DISCUSSION}

The curves obtained by plotting $\mathrm{p} K_{m}$ against $\mathrm{pH}$ have shown the presence in the enzyme of two different substrate-binding groups. The chemical nature of one of these groupings $(\mathrm{p} K \mathrm{8.2})$ is obscure, but the other group (pK at 9.4) might be $\epsilon$ - or $\alpha$-amino, sulphydryl or phenolic, all being groups with similar $\mathrm{p} K$ values. The results obtained with the protein-group-specific reagents suggested that sulphydryl might be excluded, since the inhibition $(49 \%)$ by $p$-chloromercuribenzoic acid could not be reversed by cysteine or glutathione. The experimental results did not permit an unequivocal distinction between phenolic and amino groups, except that the enzyme was completely inhibited by treatment with acetic anhydride under conditions which Fraenkel-Conrat \& Fraenkel-Conrat (1950) claim to be specific for substrate-binding grouping. If such a grouping were present in the Alcaligenes enzyme it would not necessarily be reflected in the Dixon curves but it might well confuse the experiments with protein group reagents. However, it must be remembered that most of the aldehydic reagents used in the present work would carry some form of charge at the $\mathrm{pH}$ values used and their inhibitory effect may simply be due to their combination with an oppositely charged enzyme grouping. These points are being examined further.

Additional information may be derived from the Dixon curves by consideration of rule 9 (Dixon, 1953). Rule 9 states that 'the slope in any $\mathrm{pH}$ region is numerically equal to the change of charge on... "desubstration", that is to say it is equal to the number of charges on the left-hand side of the equation

$$
\mathrm{E}+\mathrm{S} \rightleftharpoons \mathrm{ES}
$$


minus the number of charges on the right-hand side, due regard being paid to algebraic sign'. It has already been pointed out that above pH 7 there is no change in charge on any of the substrates (cf. Fig. 7). Furthermore, the Dixon curves show no evidence of change in charge of enzymesubstrate complex between pH 8 and 10. Since the charges on $\mathrm{S}$ and ES are constant between $\mathrm{pH} 8$ and 10 it follows that the enzyme group with $\mathrm{p} K$ at 8.2 must be of a type which gains a positive charge (or loses a negative charge) below $\mathrm{pH} 8.2$ to give a +1 -unit slope on the $\mathrm{p} K_{m} / \mathrm{pH}$ curves. The grouping with $\mathrm{p} K \mathbf{9 . 4}$ must be one which gains a negative charge (or loses a positive charge) above $\mathrm{pH} \mathrm{9.4} \mathrm{to}$ give a - l-unit slope. The possibility that the group with $\mathrm{p} K$ at 9.4 might be $\epsilon$ - or $\alpha$-amino is not incompatible with the -1-unit slope obtained above this $\mathrm{pH}$, since the $-\mathrm{NH}_{2}$ group would tend to lose its positive charge above $\mathrm{pH} \mathbf{9 \cdot 4}$.

It is possible that two oppositely charged groupings in the Alcaligenes enzyme are linked with substrate in the form

$$
\begin{array}{r}
\operatorname{Ar}-\mathrm{O}-\mathrm{S}) \nearrow^{0} \\
\searrow_{0^{-}}
\end{array}
$$

where the sulphur atom is, to some extent, positively charged, and this possibility is now being investigated further. Wilson \& Bergmann (1950), working with cholinesterase, and Gawron, Grelecki \& Duggan (1953), working with wheat-germ lipase, suggested that similar linkages existed between these enzymes and their respective substrates.

\section{SUMMARY}

1. The arylsulphatase of Alcaligenes metalcaligenes has been concentrated and partially separated from nucleic acid and from other enzymes.

2. Some properties of the purified enzyme have been described.

3. The effect of inhibitors and protein-groupspecific reagents, together with a study of the variation of the Michaelis constant with $\mathrm{pH}$, has given some indication as to the nature of the substrate-binding groups of the enzymes.

We are grateful to the Royal Society, the Medical Research Council and Imperial Chemical Industries Ltd. for gifts of apparatus. One of us (K.W.) is indebted to the Department of Scientific and Industrial Research for a studentship.

\section{REFERENCES}

Alberty, R. A. \& Massey, V. (1954). Biochim. biophys. Acta, 13, 347.

Aldridge, W. N. (1954). Biochem. J. 57, 692.

Arrhenius, S. (1889). Hoppe-Seyl. Z. 4, 226.

Binkley, F. (1952). J. exp. Cell Res. (Suppl.), 2, 145.

Binkley, F. (1954). Proc. Roy. Soc. B, 142, 170.

Briggs, G. E. \& Haldane, J. B. S. (1925). Biochem. J. 19, 338.

Dixon, M. (1953). Biochem. J. 55, 161.

Dodgson, K. S., Melville, T. H., Spencer, B. \& Williams, K. (1954). Biochem. J. 58, 182.

Dodgson, K. S., Rose, F.A. \& Spencer, B. (1955). Biochem.J. 60, 346.

Dodgson, K. S. \& Spencer, B. (1953). Biochem. J. 55, 315.

Dodgson, K. S., Spencer, B. \& Thomas, J. (1955). Biochem. J. $59,29$.

Dzialoszynski, L. M. (1950). Nature, Lond., 176, 157.

Einbinder, J. \& Schubert, M. (1950). J. biol. Chem. 185, 725.

Flynn, F. V. \& de Mayo, P. (1951). Lancet, 261, 235.

Fraenkal-Conrat, H. \& Fraenkal-Conrat, S. (1950): Biochim. biophys. Acta, 5, 98.

Gawron, O., Grelecki, C. J. \& Duggan, M. (1953). Arch. Biochem. Biophys. 44, 455.

Gulland, J. M., Jordan, D. O. \& Threlfall, C. J. (1947). J. chem. Soc. p. 1129.

Lowry, O. H., Roseborough, N. J., Farr, A. L. \& Randall, R. J. (1951). J. biol. Chem. 193, 265.

Lineweaver, H. \& Burk, D. (1934). J. Amer. chem. Soc. 56, 658.

Maengwyn-Davies, G. D. \& Friedenwald, J. S. (1954). Arch. Biochem. Biophys. 53, 29.

Markham, R. (1942). Biochem. J. 36, 790.

Michaelis, L. \& Menten, M. L. (1913). Biochem. Z. 49, 333.

Robinson, D., Smith, J. N., Spencer, B. \& Williams, R. T. (1952). Biochem. J. 51, 202.

Robinson, D., Smith, J. N. \& Williams, R. T. (1953). Biochem. J. 53, 125.

Rosenfeld, L. E. \& Ruchelman, A. A. (1940). Ukr.biochem. J. 16, 53.

Roy, A. B. (1953). Biochem. J. 55, 653.

Roy, A. B. (1954). Biochem. J. 57, 465.

Schmidt, G. \& Thannhauser, S. J. (1945). J. biol. Chem. $161,83$.

Soda, T. \& Yoshida, A. (1948). J. chem. Soc. Japan, 69, 119.

Warburg, O. \& Christian, W. (1941). Biochem. Z. 310, 384.

Wilson, I. \& Bergmann, F. (1950). J. biol. Chem. 186, 683. 